\title{
QUALQUER SÍLABA TORTA E SECA FEITO UM RAMO (BREVE APRESENTAÇÃO DA POESIA DE SAKUTARÔ.HAGIWARA)
}

\section{Valdinei Dias Batista}

Non chiederci la parola che squadri da ogni lato l'animo nostro informe, e a lettere de fuoco lo dichiari e risplenda come un croco perduto in mezzo a un polveroso prato

Non domandarci la formula che mondi possa aprirti, si qualche storta sillaba e secca come un ramo Codesto solo oggi possiamo dirti ciò che non siamo, ciò che non vogliamo.

\section{Eugenio Montale, "Non chiederci""}

RESUMO: A proposta do artigo é apresentar uma série de traduções de poemas de Sakutarô Hagiwara para o Português, discutindo alguns aspectos dessa poética e da poética japonesa desse período, bem como a maneira pela qual aspectos sócio-políticoeconômicos determinaram - assim como o fizeram no Ocidente - os rumos da poesia japonesa de Taishô até hoje.

1. "Não nos peças a palavra que vasculhe em cada canto/nosso ânimo informe, e com letras de fogo/ aclare e o faça arder como açafrão/ perdido em meio a poeirento prado// Nem nos perguntes a fórmula que possa abrir-te mundos,/alguma sílaba torta, sim, e seca como um ramo/Podemos dizer-te hoje apenas isto/ o que não somos, o que não queremos". Alfredo Bosi, O Ser e o Tempo da Poesia, São Paulo, Cultrix, 1983, p. 144. 
ABSTRACT: The purpose of this article is to present a series of translations of Sakutarô Hagiwara's poems to the Portuguese discussing some aspects of this poetic and the Japanese poetic of this period as well as the way that some sociologic, politic and economic aspects determined - as they did to the West - the route of Japanese poetry from Taishô till now.

PALAVRAS-CHAVE: Poesia japonesa; poesia contemporânea; poesia e sociedade; tradução de poesia.

KEYWORDS: Japanese poetry; contemporary poetry; poetry and society; translation of poetry. 


\section{SAlgueiro}

Sobre o rosto pálido e frio

Flutua a lua de elegância nobremente recendente,

Imagem envergonhada da lua.

Com palavras ternas

Converso com teu cadáver.

$\mathrm{Ah}$ ! molhado de orvalho

Salgueiro umedecido

No meio do vento da noite se mexendo.

Vagando por aqui,

Cantando as muitas felizes simpatias,

Triste desejo carnal que o homem desconhece

E é, pois, desejo carnal,

Molhando-me em lágrimas que escorrem

Eu pintarei de sangue os lábios.

Ah! que espécie de amor amar?

Brincar, agarrando-se a este pálido espírito

Soprado pelo vento.

Vagar escuro sobre a sombra do salgueiro

E é uma terna canção do cemitério. 


\section{Desejando Caminhar em Meio à Multidão}

Desejo sempre a cidade, quero estar entre as multidões ruidosas da cidade. As multidões são como grandes ondas emocionadas São grupos de vigorosos desejos e quereres escorrendo para qualquer lugar. Ah! na hora triste do crepúsculo de primavera desejar a sombra entre os vários prédios na cidade confusa.

Ser empurrado para o meio de uma grande multidão, não é um prazer?

Olhe, esta visão das multidões que escorrem.

Uma onda se sobrepondo a outra.

Ondas formando infinitas sombras e as sombras se expandindo.

Amarguras e tristezas de cada uma das pessoas

que desaparecem entre as sombras, sem deixar traços.

$\mathrm{Ah}$ ! com que tranqüilidade no coração caminho por esta rua.

$\mathrm{Ah}$ ! esta sombra alegre de grande amor e inocência.

A sensação de ser carregado por tuas alegres ondas

é quase como chorar.

Na hora triste do crepúsculo de primavera, esses grupos de pessoas nadando sob os beirais dos prédios.

Para onde e de que forma eles flutuam, eu desejaria saber.

Minha melancolia coberta pela única grande sombra da terra,

[ondas flutuantes de inocência.

Ah! não importa pra onde, não importa pra onde, quero ser empurrado por essas ondas de multidões, ondas distantes enfumaçadas no horizonte.

Para uma, só uma direção, me deixe escorrer. 

A MorTe do SAPO
Um sapo foi assassinado
Os garotos, formando um círculo, ergueram as mãos.
Todos juntos
ergueram as graciosas mãozinhas cobertas de sangue,
a lua apareceu.
No alto do morro, ergue-se uma pessoa, sob o chapéu, um rosto. 


\section{O PRÍNCIPE DE MAIO}

Caminhando sobre a relva jovem

Meus sapatos vão deixando pegadas brancas.

$\mathrm{O}$ prateado de minha bengala fina pule-se com a grama. Minhas luvas, removidas, dançam no ar.

$\mathrm{Ah}$ ! gostaria de me livrar da melancolia e de tudo

e me transformar num dócil cordeiro, pousar minha mão em sua nuca molhada e respirar a fragrância de íris nova.

Caminhando sobre a relva jovem, sou o príncipe de maio. 


\section{O Mundo dAs BaCtÉRIAS}

Pernas de bactérias, bocas de bactérias, orelhas de bactérias, narizes de bactérias.

As bactérias estão nadando.

Algumas no útero duma pessoa, algumas nas vísceras dum marisco, algumas no coração esférico da cebola, algumas no cerne duma paisagem.

As bactérias estão nadando.

As mãos das bactérias crescem cruciformes pra esquerda e direita, as pontas dos dedos se ramificam como raízes, deles crescem unhas afiadíssimas, numerosos capilares se espalham por todo canto.

As bactérias estão nadando.

No lugar onde vivem as bactérias, como se vistas através da pele dum doente, um raio de luz carmesim introduz-se tênue e somente nessa área é debilmente visível, de verdade, de verdade, se mostra insuportavelmente triste. 


\section{Caso de Homicídio}

No céu distante ecoa uma pistola.

Novamente ecoa uma pistola.

Ah! meu detetive, trajando roupas de vidro, se insinua pela janela da namorada.

O chão de cristal;

dos vãos entre os dedos

escorre sangue azul escuro.

Sobre o cadáver da triste mulher canta um frio gafanhoto.

Manhã de princípio de novembro - o detetive, trajando roupas de vidro, dobra a esquina do cruzamento. $\mathrm{Na}$ esquina, uma fonte de verão. Já sente a melancolia, o solitário detetive. Olhe, pelo distante e ermo calçamento de mármore o vilão desliza a toda velocidade! 


\section{O NADADOR}

O corpo do nadador se estende em diagonal, dois braços alongadamente se juntam, o coração do nadador é transparente feito água-viva, os olhos do nadador ouvem o tilintar dos sinos suspensos, o espírito do nadador olha a lua sobre a água. 


\section{A CHAMA $^{2}$}

Vi a chama que vermelha arde.

Feito fera

Emudecida você se cala.

No céu do entardecer da serena metrópole,

A labareda arde encantadora,

A corrente se alastra ligeira.

Num instante e tudo destrói.

Cabedais, fábricas e grandes construções.

Aspirações, honrarias, riquezas e ambições.

Tudo totalmente abrasado.

Ó chama,

Por que razões, feito fera

Emudecida você se cala?

Encerrada na triste melancolia,

Neste céu tão calmo do entardecer,

Se esgotando, em pensamento, a paixão.

2. Poema traduzido por Geny Wakisaka. Vide: Yoshimasu Gôzô, “O Poder da Imaginação Auditiva - De Santôka a Bashô", Anais do III Encontro Nacional de Professores Universitários de Língua, Literatura e Cultura Japonesa, São Paulo, CEJ/USP, 1992, pp. 24-25. Os poemas restantes foram traduzidos por Valdinei Dias Batista, diretamente do japonês e, em alguns casos, cotejados com as traduções para inglês. 


\section{REGIÃo Do PÂNTANO 3}

ULA

Onde os sapos se apinham,

Vaguei entre melancólicos pantanais.

No céu, o sol arrefecido.

A lama na trilha úmida seguia infinita,

Eu arrastei os calçados feito fera

Ora visitando as tristonhas aldeias

Com indulgência, afogado nos sonhos da danosa preguiça.

Enseada!

Anunciemos a nossa despedida

Ao pé da cabana de madeira de nossos encontros,

Você se encolhia temerosa e trêmula, tal filhote de gato,

Sob aquele sol cinzento

Soando sempre feito relógio.

Enseada! (Ula)

Estranho e tristonho coração

Enseada! Partida renovada, sem tempo de reencontro.

3. Idem. 
Já sabemos com bastante clareza que a (boa) poesia moderna - com o avanço cada vez mais vertiginoso do acúmulo capitalista e da sociedade de consumo - assumiuse ora puro individualismo (como recusa à fratura que separou o social e o psíquico no ser moderno), ora grito rouco contra essa fratura (e, ainda assim, recusa).

Contemporaneamente, frente à crescente demanda disso que se costumou chamar de "idéias pós-modernas", os estudos sobre a poesia parecem evitar olhar para o passado de modo a compreender aquela expressão artística como um produto do seu tempo - ainda que, graças tanto à magia da arte poética, como ao talento dos grandes artistas, essa poesia ainda assim ultrapasse os limites temporais e aponte para o futuro.

Em artigo da década de 1980, Ôe Kenzaburo discorre sobre a crise da literatura japonesa do Pós-Guerra, afirmando exatamente que entre os autores que se formaram nesse período, perdeu-se o poder de se criar modelos literários para as gerações futuras, o que legou, aos anos de 1980, uma literatura sem compromisso, sem metas e sem propostas para o futuro.

Essa geração, diz Kenzaburo, criou-se sob o signo do rápido crescimento econômico japonês e - quer por uma descrença numa postura ativa, quer pelo ufanismo no poderio econômico - rendeu-se ao canto de sereia do mercado. É o caso de, entre outros, Haruki Murakami:

O seu método é o de, passivamente, sem resistência, se submeter à influência da cultura popular, tecendo o seu mundo imaginário interior como se estivesse ouvindo uma música de fundo. Separado em cerca de trinta anos dos escritores do pós-guerra, Murakami exemplifica o novo tipo de escritor que assomou no cenário. Em contraste com a clareza dos temas abordados pelos escritores do pós-guerra, esta nova geração com frequiência confessa não ter interesse em temas, ocupando-se principalmente da técnica de escrever bem. Não obstante, os escritos destes autores atraem jovens leitores precisamente porque - em um nível diferente - eles eloqüentemente descrevem as qualidades de uma geração para a qual o "tema" foi perdido, que cessou de ter uma perspectiva positiva sobre o mundo ou a sociedade. Estes escritores tratam é de como uma pessoa que carece de uma postura ativa pode ter uma vida agradável e na moda na atual sociedade rica, urbana, consumidora. Este é o modelo - com um certo toque de indiferença patética, uma sombra pálida lançada pelo mundo e pela sociedade - apresentado nos escritos de Murakami ${ }^{4}$

"Sociedade rica, urbana, consumidora", por um lado, "resistência" do outro, é o que diz Kenzaburo. Percebemos, no mal-estar diagnosticado pelo escritor, ecos de períodos anteriores da literatura japonesa (e também da literatura mundial) - embora com muito mais agudeza do que no período anterior à Segunda Grande Guerra.

Kenzaburo cobra dessa geração uma postura de resistência. Resistência ao consumo, resistência à desagregação social, resistência à literatura "fácil" Opõe a

4. Ôe Kenzaburo, “A Literatura Japonesa do Pós-Guerra e o Impasse Contemporâneo”. In: Caderno de Cultura Japonesa 3, São Paulo, Aliança Cultura Brasil-Japão, 1987, pp. 12-13. 
isso uma literatura que eu chamaria de "interessada": literatura que não somente assumisse uma postura (justamente uma daquelas de que falávamos acima a respeito da poesia moderna) de recusa, mas que, ao contrário, mostrasse caminhos, produzindo no leitor, por meio do poder da imaginação, "uma experiência orgânica do futuro"5. Guardemos estas idéias de Ôe Kenzaburo, por enquanto, e partamos para um assunto correlato.

Outro "assunto" que, volta e meia, é posto em discussão é a absorção, pela cultura japonesa, de elementos estrangeiros (muitas vezes estranhos). Essa foi sempre uma postura comum do povo japonês. É sabido que o Japão importou os caracteres ${ }^{6}$ (e a partir deles desenvolveu seus silabários hiragana e katakana), manifestações artísticas (técnicas de música, pintura e literatura) da China. Mais recentemente, após a Restauração Meiji, os olhos de sua cultura se voltaram para o mundo europeu: música, literatura, moda etc. Após a rendição, ao fim da Segunda Grande Guerra, contudo, o ponto de fuga migra da Europa para os Estados Unidos da América.

Assim, se após a Restauração Meiji poetas e ficcionistas devoram (e incorporam) as obras de poetas como Baudelaire, Verlaine, Shelley; ficcionistas como Dickens, Flaubert e Dostoiévski; filósofos como Schopenhauer e Nietzsche - e conseguem, como tentaremos observar em alguns poemas de Sakutarô Hagiwara, "incorporar" essas influências ao "espírito japonês"7, ao fazer cultural próprio do Japão - após a Segunda Grande Guerra a invasão da cultura norte-americana parece não ter deixado tanto espaço para a expressão artística dentro do "espírito japonês" como antes.

Se olhamos para a poesia contemporânea japonesa, não é difícil observarmos uma certa angústia ligada à pressão dessa influência estrangeira que sufoca manifestações autóctones, na obra de poetas como Gôzô Yoshimasu, Shuntarô Tanikawa e Makoto Ôoka - para citar apenas três dos mais representativos. Se Makoto, pressionado pelo mundo contemporâneo japonês (e, é certo, mundial) se volta para a tradição do fazer poético japonês, para a poesia de corte clássico (para a visão de mundo específica do waka, por exemplo) e Shuntarô deixa penetrar nos meandros do seu poema a comicidade fina do haiku antigo e de formas poéticas cômicas da tradição japonesa, a linguagem de Gôzô Yoshimasu - um desdobramento das possibilidades poéticas de Sakutarô Hagiwara, como veremos mais adiante - denuncia a impossibilidade de comunicação da mesma ordem que aquela do aviso de Carlos Drummond de Andrade - com quem, não obstante a distância geográfica, guarda estrita proximidade:

Stop!

A vida parou

ou foi o automóvel?

5. Idem, pp. 7-8.

6. Ao contrário, entretanto, da Coréia, o Japão jamais deixou de usá-los, embora o número de ideogramas utilizados tenha diminuído sensivelmente.

7. Para melhor compreensão do yamato damashii, v. Yoshinobu Hirata. "O Destino do Espírito Japonês". In: Estudos Japoneses vol. 18, São Paulo, CEJ/USP, 1998, pp. 23-35. 
Essa pequena digressão sobre a influência externa (para não dizer "estrangeira") na cultura japonesa não vem à toa. Os estudos literários de uma cultura que não a brasileira - como é o caso, aqui, da literatura japonesa - só fazem sentido, na verdade, quando servem não somente para a compreensão dessas manifestações culturais diversas, por si sós (japonesas, chinesas, russas e assim por diante), mas se servem também para a compreensão de nossa vocação como Nação, ou seja, para a compreensão de nossa cultura e povo, em comparação com o que nos chega do exterior....

Em seu texto "Nacional por Subtração"8, Roberto Schwarz aborda o tema da "nacionalidade" - em termos de cultura, ao menos - aqui no Brasil, concluindo que, aqui, contraditoriamente (já que país produzido por mescla de várias culturas) a ideologia do nacionalismo (em geral sob a bandeira do patriotismo) afirma que somente chegaremos ao que é nacional se excluirmos o que não o é. É um pensamento que volta e meia ronda os ares da nação...

A literatura é, muitas das vezes, um "reflexo" - ainda que pálido - do que acontece na história dum país, seja ela "engajada", "interessada", ou não. No final, entretanto, o escritor de tal maneira está imerso na História de seu povo que é praticamente impossível que sua literatura não mostre isso, de uma forma ou de outra.

O Japão, como vimos acima, se criou, como nação, importando idéias e fazeres de culturas afins. Da China, principalmente. Após a vitória do Capitalismo mundial na sua forma imperialista, o Japão nitidamente rendeu-se ao american way of life, ao fast food McDonald's e à música descartável, e por isso pop. Foi uma opção social e uma imposição exterior ao mesmo tempo: o vencido se rendeu ao vencedor. $O$ fato é que a literatura contemporânea japonesa nos mostra isso ora como aceitação (como é o caso de Haruki Murakami, segundo Ôe Kenzaburo), ora como resistência (como é o caso de Gôzô Yoshimasu).

O corvo crocita;

também eu estou só.

SANTÔKA

Se Mallarmé criou seguidores por destruir a palavra poética e se arriscar a se deixar seduzir pelo abismo da mudez, Baudelaire - o lírico no auge do capitalismo, como lhe chamou Walter Benjamin - arrebanhou seguidores pelo risco de descobrir uma arte fruto de atitudes modernas e por buscar, em meio ao mercado (leia-se "Mercado") e a balbúrdia da vida moderna, uma nesga de beleza que não significasse naturalidade ou destruição, mas criação.

Foi isso, aliás, que lhe chamou a atenção em Edgar Allan Poe: a racionalidade a serviço da criação da fantasia. Há quem diga que o Poe de Baudelaire é uma criação

8. Roberto Schwarz, "Nacional por Subtração", Que Horas São?, São Paulo, Cia. das Letras, 1987. 
deste, que costumava "melhorar" a linguagem do norte-americano, mas isso é simples fantasia. Sabe isso quem já leu The raven e Ulalume. Sakutarô Hagiwara foi um dos que leu.

Baudelaire afirmava, em Pequenos Poemas em Prosa, que "o poeta goza desse incomparável privilégio de poder, à sua vontade, ser ele mesmo e outro". Ou seja, toda poesia moderna pode tanto mascarar como desnudar seu autor, é esse o seu privilégio.

Como sabemos, a sociedade do Japão da era Meiji vê nascer, juntamente com o afluxo da cultura européia, o clamor pela expressão individual, em oposição às relações tradicionais japonesas, baseadas no apagamento da individualidade em prol da coletividade. Dentro das normas de tal sociedade, evidentemente se negava ao poeta esse privilégio de que falava Charles Baudelaire e do qual Edgar Allan Poe partilhava.

Ambos foram, sem sombra de dúvida, as grandes influências estrangeiras de Sakutarô Hagiwara. O dandismo e o espírito aristocrático, a obsessão pela crueldade do mundo moderno, a fascinação pelas multidões em crescimento, mesmerizadas pela mercadoria: essas suas maiores influências.

Hagiwara foi, pois, um típico homem da modernidade: era fotógrafo, mágico, músico, desenhava plantas arquitetônicas, chegando a construir a própria casa e segundo opinião do insuspeito (e grande) poeta japonês Gôzô Yoshimasu - um admirável alienado.

Grande parte dessa admirável alienação a que se refere Yoshimasu é exatamente o quinhão de contribuição que Sakutarô Hagiwara trouxe à poesia japonesa: o valor da melodia (trazido da música) na poesia escrita e declamada. A dificuldade, aliás, da tradução de seus poemas com toda sua riqueza vem exatamente daí: a linha melódica imprimida ao poema, o valor musical de vocábulos e sílabas, bem como a sonoridade das onomatopéias e sinestesias são algo intraduzível. Esse é um aspecto que deixaremos de lado ao observamos seus poemas mais de perto, reportando-nos a eles somente onde for estritamente necessário.

Inegável também é, por outro lado, a influência que Sakutarô sofreu, em sua obra, de seus predecessores (mais acentuadamente de Hakushû Kitahara). No entanto, é evidente, ao longo de sua obra, mais acentuadamente no livro Tsuki ni hoeru (Latir para a Lua), a influência de grandes nomes da literatura ocidental como Charles Baudelaire, Edgar Allan Poe, bem como da filosofia de Arthur Schoppenhauer e Nietzsche e, não menos importante, dos demônios interiores que infestam o mundo ficcional de Dostoiévski. Leiam-se os versos seguintes:

Sobre o rosto pálido e frio

Flutua a lua de elegância nobremente recendente,

Imagem envergonhada da lua.

Com palavras ternas

Converso com teu cadáver.

A imagem envergonhada da lua - cuja elegância "recende" como uma fragrância - flutua sobre o rosto morto e o poeta conversa com o cadáver. Vemos em Hagiwara a mesma fascinação pela morte, pela fragilidade da vida humana perante as demandas 
da modernidade - ao mesmo tempo desejo e repugnância - que vemos nas Flores do Mal, de Charles Baudelaire, ou nas Histórias Extraordinárias e nos poemas $O$ Corvo e Ulalume, de Edgar Allan Poe.

Comparemos alguns versos de Poe e Hagiwara:

ULA

Onde os sapos se apinham,

Vaguei entre melancólicos pantanais.

No céu, o sol arrefecido.

A lama na trilha úmida seguia infinita,

Eu arrastei os calçados feito fera

Ora visitando as tristonhas aldeias

Com indulgência, afogado nos sonhos da danosa preguiça9.

O poeta (ou o eu lírico?) vaga pela melancolia dos pantanais, numa atmosfera úmida em que se misturam a indolência preguiçosa e a tristeza do ambiente sem sol e frio. É uma atmosfera muito parecida à do poema Ulalume de Poe, em que os primeiros ecos do outono se fazem sentir num começo de outubro do mais "imemorável ano" de sua vida:

Os céus eram cinzas, eram sóbrios;

As folhas crispadas e secas,

As folhas eram murchas e secas;

Era noite no solitário outubro

Do mais imemorável ano.

Ambos os poemas (e poetas) apresentam o ambiente insalubre, mórbido, em que introduzirão a história de sua amada. Vemos que em ambos a modernidade aguça a ânsia pela morbidez, pela crueldade escondida por trás das fachadas dos prédios que começam a se erguer nos grandes centros e pela penumbra dos becos noturnos que já começam a se iluminar devido ao fervilhar da vida noturna moderna. Esse paradoxal desejo pelo que degrada aparece, juntamente com a novidade da velocidade moderna em $A$ une passante, de Charles Baudelaire, que produzirá ecos na obra de Hagiwara:

Eu, eu bebia, como um extravagante,

Em seu olhar, céu lívido ou grão do furacão,

A doçura que fascina e o prazer que mata.

O poeta prossegue falando à beldade que encontra: "Não te verei mais senão na eternidade?" "Alhures, bem longe daqui! tarde demais! jamais talvez!" A beldade se perdeu, veloz como o mundo que passa a rodeá-la, nas hordas que vagam pelas grandes cidades. Percebemos no poema de Baudelaire a consciência de que mergulhar nesse mundo, se render ao seu chamado, é ao mesmo tempo suicídio. Mas é inevitável. O

9. “A Chama” Tradução de Geny Wakisaka. Ver nota 2. 
flaneur (que aparece em Poe e Hagiwara como o detetive voyer) precisa ver a qualquer custo.

Desse modo, a poesia de Sakutarô Hagiwara é, antes de qualquer coisa, um convite ao mergulho em outro tempo da poesia japonesa, um tempo que, até certo ponto, antecipa experiências mais radicais como as de Yoshimasu Gôzô - dos anos sessenta em diante - ou, no universo criativo do haicai, as experiências de Santôka, entre outros ${ }^{10}$ É bom, desse modo, que apliquemos a Hagiwara as idéias contidas no verso de Montale da epígrafe a este texto: "ciò che non siamo, ciò che non vogliamo", e não procuremos exigir dele mais que isso.

Aliás, todo o frescor do experimento, bem como toda a penumbra (ou mesmo a escuridão quase total, como veremos) da arte poética japonesa moderna está presente em seus poemas. É somente isso que ele tem a nos oferecer, e não é pouco.

\section{III}

No telhado sobre o quarto de dormir, dois gatos (de que sexo?) se cumprimentam, rabo em riste: "Boa noite!" - um diz para o outro. Um deles faz barulho excessivo, ao que o outro retruca: "Miaaaaau, o Senhor desta casa está doente!" Este é o poema "Gatos", do livro Uivando para a Lua, de 1918.

Todo o poema é percorrido, ao mesmo tempo, por um tom cômico e uma atmosfera algo erótica, um clima de cio - na possibilidade de serem os gatos de sexo oposto -, tudo contrastado com a doença do Senhor da casa. Também aqui o mórbido e o erótico se entrecruzam, "a doçura que fascina e o prazer que mata", Mal e Bem partilham o mesmo espaço, o mesmo tempo.

Em muitos poemas de Sakutarô Hagiwara, vemos aparecer a imagem assustadora que a Metrópole em ascensão começa a provocar nos mais sensíveis. Em alguns momentos essa imagem nos remete à Paris de Baudelaire, mas em alguns outros, podem-se vislumbrar pelas ruas dessa cidade perdida na escuridão da noite as multidões de almas sem rumo, vagando pelos círculos do Inferno, no poema de Dante.

Em "Desejando Caminhar em Meio à Multidão" a imagem (ou seria uma visão?) do mundo moderno transformado nessa espécie de inferno me parece clara:

Desejo sempre a cidade,

quero estar entre as multidões ruidosas da cidade.

As multidões são como grandes ondas emocionadas

São grupos de vigorosos desejos e quereres escorrendo para qualquer lugar.

Como a personagem do conto "O Homem da Multidão". de Edgar Allan Poe, o eu lírico deseja mergulhar na multidão, misturar-se às "multidões ruidosas da cidade", que são, para ele, nada mais que outros "desejos e quereres" vigorosos como uma

10. Ver: Valdinei Dias Batista, "Haicai, Tabaco e Saquê", Estudos Japoneses, vol. 18, São Paulo, CEJ/USP, 1998, pp. 101-113. 
enxurrada que nada pode parar. É interessante notar, neste poema e, por exemplo, em A Chama, poemas que têm como cenário a Metrópole, como tudo lembra catástrofes inundação, incêndio - que o poder humano não consegue conter. A vida na Metrópole, por isso mesmo, provoca a indecisão na escolha entre Eros e Tanatos: é ao mesmo tempo prazer e derrota:

Ah! na hora triste do crepúsculo de primavera desejar a sombra entre os vários prédios na cidade confusa.

Ser empurrado para o meio de uma grande multidão, não é um prazer?

[...]

Amarguras e tristezas de cada uma das pessoas que desaparecem entre as sombras, sem deixar traços.

Ah! com que tranquiilidade no coração caminho por esta rua.

Ah! esta sombra alegre de grande amor e inocência.

A sensação de ser carregado por tuas alegres ondas

é quase como chorar.

O amor e a inocência que se encontram pelas ruas têm, paradoxalmente, "sombra alegre", formando um evidente oxímoro, pois a sombra carrega sempre em si algo de trevas, de tristeza; ainda assim, nas ruas da Metrópole movida pela vertigem moderna, é alegre. Por esse motivo, deixar-se levar por essas multidões, pelas "alegres ondas" "é quase como chorar" Ao que parece, a alegria moderna traz em si o germe da tristeza, o que explica que, nesse turbilhão, "amarguras e tristezas de cada uma das pessoas" desapareçam, "sem deixar traços"

Na hora triste do crepúsculo de primavera, esses grupos de pessoas nadando sob os beirais dos prédios.

Para onde e de que forma eles flutuam, eu desejaria saber.

Minha melancolia coberta pela única grande sombra da terra,

[ondas flutuantes de inocência.

Ah! não importa pra onde, não importa pra onde, quero ser empurrado por essas ondas de multidões, ondas distantes enfumaçadas no horizonte.

Para uma, só uma direção, me deixe escorrer.

Dissemos, linhas atrás, que a descrição das multidões a vagar pelas ruas da metrópole guarda semelhanças com as hordas de almas infelizes que vagam pelos círculos do inferno de Dante. A diferença é, entretanto, óbvia a todo leitor. Em Dante, não há espaço para o prazer da vertigem causada pelo Mal, como há em Baudelaire ("La charogne" é um exemplo eloqüente) ou em Sakutarô. A semelhança mais evidente, contudo, é que o inferno mostrado a nós por Dante Alighieri é cheio de esperança. Para Dante, a inversão maligna que se espelha no Inferno é promessa que o Futuro encontrará o mundo novamente de pés no chão, e não de cabeça para baixo, como no Inferno ${ }^{11}$

11. Lembrar que o Inferno se forma com o corpo invertido de Belzebu, atirado do Céu após a revolta. 
Flávio Aguiar fala da visão infernal na obra de Dante da seguinte maneira:

Dante vê a verdade do Inferno: é por culpa do Inferno - e das almas que nele cumprem sua pena eterna - que o mundo perdeu o rumo. Se o Inferno é de pernas para o ar, é porque assim é o mundo medieval que Dante conhece. Essa visão dantesca, que o leitor partilha, é conhecimento, faz-se conhecimento e utopia: ela traz em si a esperança do Paraíso, ou seja, o futuro colocará o mundo na posição correta ${ }^{12}$

Para a visão de Sakutarô a modernidade pode até ser essa inversão, mas não há por que se esperar o Paraíso futuro. O presente é a vertigem sedutora e libertadora. Se o mundo perdeu o rumo, é exatamente esse Caos o seu desejo. O poeta deseja o mergulho nessa bagunça, nesse mundo de pernas pro ar, nessa onda de massificação.

A reificação atingiu aqui seu limite máximo, para ele. Por isso, não há por que se debater, lutar contra. Sakutarô Hagiwara parece propor aquele mergulho que Walter Benjamin proporá, um mergulho no mundo da barbárie em que, no último instante, o agente tentasse se agarrar em algo, fugindo à destruição. Tanto o pensador quanto o poeta sabiam que, entretanto, a experiência era perigosa, mas ao mesmo tempo sedutora, algo como a experiência de Ulisses seduzido pelo canto das sereias e amarrado ao poste do navio. Sakutarô parece querer soltar as amarras.

Além disso, como lembra também Walter Benjamin ${ }^{13}$, esse mergulho tem algo de heróico, que é a imagem do artista para Baudelaire. Para este, o espectador aprecia o esforço do artista, seu suor e, por que não?, seu sofrimento. Bastante disso se encontra na obra de Sakutarô, essa imagem do herói, alguém que se sobressai por um esforço qualquer ou por uma peculiaridade (característica, aliás, presente tanto nos românticos, como nos modernos): heroísmo, voluntariedade, originalidade. É isso o que nos transmite a idéia do sofrimento, do esforço, da grandeza (heroísmo), da busca e do desejo (voluntariedade), da inspiração, do dandismo, da excentricidade (originalidade).

Lembra Victor Fournel, contudo, que existe diferença entre oflaneur e o badaud: o primeiro mergulha na vertigem da multidão (e portanto da modernidade), mas mantém-se indivíduo. $O$ segundo mergulha de tal maneira que já não é mais ser humano, é multidão, público ${ }^{14}$

Oferecer uma visão literária a um público é, antes de tudo, romper com a tradição não como um corte abrupto, mas como um salto adiante que, ao mesmo tempo que rompe com o tradicional, confirmando-o, experimenta um novo modo de ação e novas alianças com a cultura.

Entretanto, esse rompimento deve, ao mesmo tempo, pressupor a tradição e desejar que a instauração da contemporaneidade crie uma nova antigüidade. A modernidade quer tornar-se tradição. Toda modernidade aspira à imortalidade.

12. Flávio Wolf Aguiar, $O$ Olhar, São Paulo, Cia. das Letras, pp. 317-318.

13 Walter Benjamin, "A Modernidade", A Modernidade e os Modernos, Rio de Janeiro, Tempo Brasileiro, 1975, p. 7.

14. Victor Fournel, Ce qu'on voit dans les rues de Paris, 1858. Apud Walter Benjamin, "A Modernidade", A Modernidade e os Modernos, Rio de Janeiro, Tempo Brasileiro, 1975, p. 32, nota 12. 
Outro aspecto da modernidade na poesia de Baudelaire é a voracidade do olhar. A cidade, a multidão, a arte só existem graças ao olhar. O flaneur, seu herói mais comum, é aquele que se delicia com olhar o mundo de maneira interessada, mergulhar, com esse olhar, nas vagas do mundo moderno sem perder sua individualidade. Ele é, nos contos de Poe - "Os Assassinatos da Rua Morgue" e "O Mistério de Marie Rogêt" são excelentes exemplos - o detetive perspicaz e meticuloso que não perde, por ser observador (controla o olhar racionalmente), qualquer pequena pista.

O flaneur aparece com bastante clareza, na obra de Sakutarô - na sua forma "detetive amador", aquele que se delicia com o olhar ${ }^{15}$-, primeiramente no poema "Caso de Homicídio", em que se mostra de forma bem clara a influência de Poe via Baudelaire: um detetive depara com o cadáver de uma mulher assassinada a tiros, mas o caso, até onde podemos apreender isso no poema, não se resolve, já que o matador se perde pelas ruas e calçadas da cidade.

Em seguida, vemos o mesmo flaneur aparecer no poema "Morte do Sapo", em que crianças - sob o olhar enigmático de alguém cujo rosto se esconde sob a sombra do chapéu - praticam um ritual maligno de dissecção de um sapo.

Em "Caso de Homicídio", o primeiro enigma que se coloca para o leitor é a vestimenta do detetive-amante: ao mesmo tempo veste e despe, sendo transparência:

No céu distante ecoa uma pistola.

Novamente ecoa uma pistola.

Ah! meu detetive, trajando roupas de vidro, se insinua pela janela da namorada.

Dessa forma, o poeta - ou melhor, o detetive-amante - aparece em toda sua nudez. A nudez, entretanto, é dupla: é tanto a nudez que é produto da transparência da veste vítrea, como nudez causada pela impotência, já que ao fim do "conto" o vilão escapa a toda velocidade. $\mathrm{Na}$ cena do crime restam o cadáver ensangüentado da triste amada, o impotente flaneur, a elegia cantada pelo frio inseto:

O chão de cristal;

dos vãos entre os dedos

escorre sangue azul escuro.

Sobre o cadáver da triste mulher

canta um frio gafanhoto.

[...]

Olhe, pelo distante e ermo calçamento de mármore

o vilão desliza a toda velocidade!

Cruzam-se neste poema vários motivos caros a esse olhar moderno: a morbidez, o erotismo, a elegância, a velocidade com que o vilão mergulha na cidade e desaparece.

A crueldade parece nos mostrar um aspecto da modernidade. Ela destrói ao mesmo tempo que constrói, expõe a ferida e oferece um medicamento. Vemos em

15. Lembrar que Sakutarô foi fotógrafo, como foi dito acima. 
muitos momentos da poesia de Hagiwara a mesma atenção prestada à crueldade que encontramos em Poe e Baudelaire. Em "A Morte do Sapo", hei-la que reaparece:

Um sapo foi assassinado.

Os garotos, formando um círculo, ergueram as mãos.

Todos juntos

ergueram as graciosas mãozinhas cobertas de sangue,

a lua apareceu.

No alto do morro, ergue-se uma pessoa,

sob o chapéu, um rosto.

A cena é quase um ritual. Os garotos de "graciosas mãozinhas" cobertas de sangue parecem oferecer o sapo em sacrifício à lua, que então aparece. No alto do morro, oflaneur observa o ritual macabro. Há ecos, neste poema, de "Une charogne", de Baudelaire. Lá, o poeta relembra à amada a visão de uma carcaça de animal em putrefação, com as pernas abertas como uma mulher lasciva. A observação é, também lá, como um ritual feito aqueles do século XVII, na Europa, em que várias pessoas iam ao cemitério observar nas sepulturas abertas como é efêmera a vida. Exatamente como na cena de Hamlet, de William Shakespeare, em que o príncipe e Horácio observam a sepultura aberta de Yorick, o bobo do rei, e reclamam sobre a brevidade da vida.

A nudez que a modernidade expõe é, para Baudelaire, guardadas as proporções históricas, de mesmo grau. A perda da aura, a crueza a que é exposta a realidade do mundo moderno, nos lembra a todo instante que tudo passa.

No poema "As Bactérias", contudo, além da morbidez já mencionada a respeito de outros poemas, o leitor sente um desconforto crescente a cada verso. O poema todo parece impregnado por uma atmosfera nauseante. Logo de início, as bactérias são personificadas da seguinte maneira:

Pernas de bactérias, bocas de bactérias, orelhas de bactérias, narizes de bactérias.

As bactérias estão nadando.

O verso "As bactérias estão nadando" percorre todo o poema até o fim, como uma espécie de vaticínio mórbido. Parece anunciar a invasão do planeta por esses seres recém-descobertos. É interessante notar que a palavra "bactérias" (no original bakuteria, do latim bacteria, plural de bacterium), que deveria, por se tratar de palavra estrangeira, ser grafada em caracteres katakana, é grafada em hiragana. Segundo o autor, os caracteres hiragana dão à palavra a impressão de um ajuntamento de bactérias que lhe pareceu muito expressivo para o poema.

Conforme o vaticínio do verso, as bactérias parecem invadir tudo o que encontram pela frente: 
Algumas no útero duma pessoa, algumas nas vísceras dum marisco, algumas no coração esférico da cebola, algumas no cerne duma paisagem.

Como numa guerra, como as cidades que começam a se formar e crescer, como a modernidade vertiginosa, as bactérias se espalham e lançam dedos que se ramificam:

As mãos das bactérias crescem cruciformes pra esquerda e direita, as pontas dos dedos se ramificam como raízes, deles crescem unhas afiadíssimas, numerosos capilares se espalham por todo canto.

Vimos nos trechos de poemas acima os principais aspectos que se mostram na poesia de Hagiwara Sakutarô. Poderíamos ver neles, ainda, o que neles existe de continuidade com a tradição do poema japonês (o colorido pictórico de muitos deles não seria um bom exemplo?), o que poderia resultar num longo ensaio, mas preferimos nos ater somente às influências ocidentais que neles aparecem e que mostram clara necessidade de expressão individual, mais do que a expressão coletiva via laços da tradição.

\section{IV}

Dá-nos do teu Amor as claras lágrimas Para conforto de tão duras penas.

AUGUSTO FREDERICO SCHMIDT

Linhas atrás dissemos que a poesia de Sakutarô Hagiwara era, de certa maneira, um prenúncio da experiência angustiada da poesia contemporânea de Gôzô Yoshimasu. Isto tanto explica Yoshimasu, como explica Hagiwara. Vejamos brevemente alguns aspectos que se mostram na poesia de Yoshimasu, para depois retornarmos à de Sakutarô.

Em Osíris, o Deus de Pedra, lançado em tradução, no Brasil, as imagens da pedra são constantes, como é constante, nos versos desse poeta, a dificuldade da comunicação no mundo pós-industrial. A linguagem, assim, se dá sob o signo da incomunicabilidade. A mitologia egípcia - de onde o autor buscou a idéia de um deus não talhado, mas formado em pedra, pode nos esclarecer muita coisa.

Osíris era a dupla inicial Sol-Lua. Morto e esquartejado por Seth, tendo seus membros de divindade espalhados pelo Egito (ou seja, por todo o universo conhecido pelo mito), é trazido à vida pela irmã Ísis, após muito esforço. Seu retorno à vida deveria significar o restabelecimento da dupla inicial, ou seja, a vitória do princípio original. Isso, entretanto, tornou-se impossível: "Osíris, ligado à morte, tolhido em 
suas faixas, é o Mundo, atado, petrificado, cristalizado e materializado, privado de liberdade e submetido às leis da Natureza e aos ritmos implacáveis do Destino..."16

É esse o mundo pós-industrial que transparece por entre os versos agudos e estilhaçados de Yoshimasu. Perpassa sua poesia a mesma angústia que brota da poesia de Sakutarô Hagiwara sem, contudo, a euforia pela invasão da modernidade, que em ambos é o mote. O Osíris pós-industrial de Yoshimasu, feito em pedra, jamais terá seus fragmentos re-unidos por qualquer Ísis.

Diz a antropologia filosófica que a todo mito corresponde um rito que o refaz e atualiza. No mundo de Yoshimasu a fragmentação chegou ao limite máximo: o ritual da re-união dos pedaços de Osíris não pode mais acontecer, o amálgama se perdeu. Ao poeta, resta somente a sua reclusão num canto transformado em concha - espiralado sempre voltando ao começo, tentando, e nunca conseguindo, reinstituir o mito por novos ritos. O ritual da sua poesia, porém, não corresponde mais a um mito - Yin e Yang se rasgaram, o tei-gi se rompeu. A mundo contemporâneo se tornou impermeável à palavra poética.

Se no tempo de Sakutarô Hagiwara havia espaço para o ufanismo com respeito à modernidade (como, de resto, na euforia dos artistas modernistas da década de 1920 no Brasil), o que funcionava como bálsamo para as feridas causadas pelo atrito da expressão individual num meio em que a tradição clamava pelo apagamento do indivíduo, o mundo pós-moderno - que rejeita a História como refugo e ergue, em seu lugar, um altar para o deus Mercado - não guarda espaço para euforias, o que mantém a ferida aberta, sem curativos.

De certo modo, podemos ver a poesia de Gôzô Yoshimasu como o cumprimento da promessa tornada linguagem da poesia de Sakutarô Hagiwara. A linguagem da poesia deste surge da angústia causada pela pressão excessiva que acomete o indivíduo em plena ascensão: a pressão da modernidade, da individualização e dos clamores imperialistas que prenunciavam a Segunda Grande Guerra.

A linguagem poética de Yoshimasu é produto de um tempo em que o indivíduo alcançou o máximo do isolamento permitido. A coletividade, por seu turno, só se mostra por meio do toque mágico da deusa Tecnologia, a Ísis da pós-modernidade.

A poesia contemporânea não tem mais público (no sentido estrito da palavra), tem estudiosos e apreciadores; por outro lado, o poeta não tem outra forma de expressão que não ela: a comunicação se tornou impossível, criou-se um curto-circuito na linguagem poética, por isso ela só fala de si mesma, mesmo quando fala do mundo. Tornou-se, na poesia de Gôzô Yoshimasu, concha, caracol: ambos seres vivos enclausurados em celas calcárias, de pedra.

O que deveria ser rito - perpetuação e reavivamento do Mito primordial - tornouse isso também outro mito: os cacos de Osíris se colaram, mas os fragmentos não reformaram um deus uno como o original. Osíris - para ainda destrinçarmos os meandros da poesia de Yoshimasu - o deus civilizador do Egito, o criador da Agricultura, cultivador dos vinhedos, aquele que instituiu leis humanas e suaves em substituição

16. Luiz Carlos Teixeira Freitas, "Prefácio”, O Livro dos Mortos do Antigo Egito, São Paulo, Hemus, p. 16. 
aos costumes grosseiros e bárbaros; enfim, o criador das festas e dos cerimoniais de culto, esse deus tornou-se pedra ao mesmo tempo inteiriça mas fragmentada.

Essa é a imagem do mundo contemporâneo na poesia de Yoshimasu Gôzô: o que nos parece homogeneidade camufla uma ruptura profunda que não pode mais ser superada. $\mathrm{O}$ que parece continuidade é incomunicabilidade. Cultura se mostra como acúmulo de informação.

É difícil dizer como age a ideologia em nosso tempo, mas seus efeitos são evidentes ao bom observador. Já se disse que ela é, hoje em dia, sinônimo de cinismo. A linguagem de Yoshimasu mostra ao provável leitor as veias abertas do mundo contemporâneo: se se camufla a incomunicabilidade sob a máscara da continuidade, a informação sob a máscara da cultura, camufla-se, além de tudo, a barbárie sob a máscara da Civilização. Osíris foi derrotado totalmente e a barbárie chamou-se a si mesma de civilização. Que pode a poesia fazer senão protestar em forma de silêncio?

Vimos, na poesia de Sakutarô Hagiwara, um olhar sobre o Presente (a visão da Metrópole) que provoca visões do Futuro. Se prestarmos mais atenção à poesia antiga japonesa, perceberemos que, em grande parte dela, a melancolia surge da percepção da efemeridade da vida como produto da observação da natureza. Isso ocorria, no mais das vezes, em cerimônias tais como as de apreciação do desabrochar das flores de ameixeira ou cerejeira. Era, então, ao mesmo tempo uma celebração pela passagem do tempo (as estações do ano) e uma reflexão sobre a brevidade da vida.

O poeta, em muitos momentos, declara-se desejoso de se livrar da sua melancolia:

Ah! gostaria de me livrar da melancolia e de tudo

e me transformar num dócil cordeiro [...].

Se em tempos antigos foi assim, para o poeta japonês dos grandes centros em expansão a sensação de melancolia (e mais que isso, morbidez) provocada pela efemeridade da vida surge com a percepção da degeneração da qualidade de vida nos grandes centros, da perda de profundidade na vida e nas artes modernas e, paradoxalmente, do desejo de mergulhar de cabeça nesse abismo em que se transformou a vida do homem neste século.

Assim como para Baudelaire (e, portanto, para Poe), para Sakutarô Hagiwara, o melhor aspecto do mundo moderno é exatamente o que nele ainda sobrevive de antigo, de arcaico. E o que é isso, senão um imenso clamor de Futuro, o grão da Esperança, a semente da Utopia que toda grande poesia digna desse nome contém?

A beleza que emana, portanto, da poesia de Sakutarô Hagiwara - e mais recentemente da poesia de Shuntarô Tanikawa, Ôoka Makoto e Yoshimasu Gôzô, projetos de poesia que resistem à massificação, de uma maneira ou de outra - é exatamente esse desejo de que o presente seja somente a ponte para o futuro (isso nos parece tão óbvio que sequer lhe damos a devida atenção). Essa é uma poesia consciente de que a função do moderno (e do contemporâneo) é instaurar a Antigüidade no Futuro, é cravar a Utopia na Desesperança.

É justo lembrar que muitas vezes as "torres de ametista" da poesia nos mostram exatamente uma forma de negação, são o sintoma de uma doença social ou de períodos 
críticos da história e da cultura de um povo. Percebemos, pela poética de Sakutarô Hagiwara, que, muitas vezes, quando a poesia tartamudeia, gagueja, soluça ou se esconde, é de bom alvitre que a crítica lhe preste a atenção devida. Mais que tudo, é preciso que não se exija dela senão "qualche storta sillaba e secca come un ramo", e que se compreenda que, então, os poetas nos podem dizer apenas o que não são, apenas o que não querem.

É preciso que nós, no presente, não exijamos mais do que eles nos podem oferecer. No futuro...

\section{Bibliografia}

Aguiar, Flávio Wolf et allii. O Olhar. S. Paulo, Cia. das Letras, pp. 317-318.

BATISTA, Valdinei Dias. "Haicai, Tabaco e Saquê". Estudos Japoneses vol. 18. São Paulo, CEJ/ USP, 1998, pp. 101-113.

"Via-Láctea de Gôzô Yoshimasu - O Poeta e a Imensidão" Estudos Japoneses vol. 14. São Paulo, CEJ/USP, 1994, pp. 111-116.

BENJAMIN, Walter. "A Modernidade". A Modernidade e os Modernos. Rio de Janeiro, Tempo Brasileiro, 1975, p. 7.

Gôzô, Yoshimasu. "O Poder da Imaginação Auditiva - De Santôka a Bashô" Anais do III Encontro Nacional de Professores Universitários de Língua, Literatura e Cultura Japonesa. São Paulo, CEJ/USP, 1992.

HIRATA, Yoshinobu. "O Destino do Espírito Japonês". In: Estudos Japoneses vol. 18. São Paulo, CEJ/USP, 1998, pp. 23-35.

KenZABURo, Ôe. "A Literatura Japonesa do Pós-Guerra e o Impasse Contemporâneo" In: Caderno de Cultura Japonesa 3. São Paulo, Aliança Cultural Brasil-Japão, 1987, pp. 12-13.

ÔOKA, Makoto e SHUNTARÔ, Tanikawa (org.). Utsukushii nihon no shi ["Bela Poesia do Japão"]. Tóquio, Iwanami, 1990. 